\title{
Oceanisphaera litoralis gen. nov., sp. nov., a novel halophilic bacterium from marine bottom sediments
}

Correspondence

E. Stackebrandt

Erko@dsmz.de

\author{
L. A. Romanenko, ${ }^{1}$ P. Schumann, ${ }^{2}$ N. V. Zhukova, ${ }^{3}$ M. Rohde, ${ }^{4}$ \\ V. V. Mikhailov ${ }^{1}$ and E. Stackebrandt ${ }^{2}$
}

${ }^{1}$ Pacific Institute of Bioorganic Chemistry, Far-Eastern Branch, Russian Academy of Sciences, 690022 Vladivostok, Prospekt 100 Let Vladivostoku, 159, Russia

${ }^{2} \mathrm{DSMZ}$ - Deutsche Sammlung von Mikroorganismen und Zellkulturen GmbH, Mascheroder Weg 1b, D-38124 Braunschweig, Germany

${ }^{3}$ Institute of Marine Biology, Far-Eastern Branch, Russian Academy of Sciences, 690041 Vladivostok, Russia

${ }^{4} \mathrm{GBF}$ - Gesellschaft für Biotechnologische Forschung GmbH, D-38124 Braunschweig, Germany

A polyphasic taxonomic study was performed to characterize a new bacterial isolate, designated KMM $3654^{\top}$, from a marine bottom sand sample. The strain was Gram-negative, encapsulated, aerobic, moderately halophilic and grew between 0.5 and $10 \% \mathrm{NaCl}$ and at $4-42{ }^{\circ} \mathrm{C}$. Its DNA $\mathrm{G}+\mathrm{C}$ content was $56 \cdot 4 \mathrm{~mol} \%$. Isolate $\mathrm{KMM} 3654^{\top}$ was phylogenetically closely related to members of the genus Oceanimonas, showing $96 \cdot 7$ and $95.6 \% 16 \mathrm{~S}$ rRNA gene sequence similarity to Oceanimonas doudoroffii DSM $7028^{\top}$ and Oceanimonas baumannii ATCC $700832^{\top}$, respectively. Strain KMM $3654^{\top}$ shared some physiological and chemotaxonomic properties with these two Oceanimonas species, but differed from them in morphology, growth at $4{ }^{\circ} \mathrm{C}$, urease activity, weak phenol degradation and utilization of phenylacetate. On the basis of phenotypic and phylogenetic evidence, Oceanisphaera litoralis gen. nov., sp. nov. is proposed, with the type strain KMM $3654^{\top}$ (=DSM $15406^{\top}$ ).
Strain KMM $3654^{\mathrm{T}}$ was isolated from a bottom sand sample that was collected from the coastal sea-water area of Peter the Great Bay, Sea of Japan, Russia, in June 2002. A bottom sand sample was retrieved at a depth of $0.2 \mathrm{~m}$, placed in a sterile tube and diluted serially with sterile sea water. An aliquot of each dilution was spread on marine 2216 agar (MA; Difco) and inoculated at $28^{\circ} \mathrm{C}$ for 7 days. Cultures were stored at $-80{ }^{\circ} \mathrm{C}$ in liquid nutrient medium supplemented with $30 \%(\mathrm{v} / \mathrm{v})$ glycerol. Strain KMM $3654^{\mathrm{T}}$ was grown routinely on MA or tryptone soy agar (TSA) or in marine broth $2216(\mathrm{MB})$ (all from Difco).

Cell morphology was examined by transmission and scanning electron microscopy of cells grown in $\mathrm{MB}$ after $30 \mathrm{~h}$ incubation. Cells were fixed with $1 \%(\mathrm{v} / \mathrm{v})$ glutaraldehyde and negatively stained with $4 \%(\mathrm{w} / \mathrm{v})$ aqueous uranyl acetate and carbon film. Samples were examined by using a Zeiss transmission electron microscope (model TEM910) at an acceleration voltage of $80 \mathrm{kV}$ at calibrated magnifications. Gram-reaction, oxidase, catalase and hydrolysis of starch, casein, DNA, chitin and gelatin were tested as described by Baumann et al. (1972) and Smibert \& Krieg

The GenBank/EMBL/DDBJ accession number for the $16 \mathrm{~S}$ rDNA sequence of $\mathrm{KMM} 3654^{\top}$ is AJ550470.
(1994). Growth at $4-45^{\circ} \mathrm{C}$ was determined on MA and TSA. Tolerance of $\mathrm{NaCl}$ was tested by using glucose-peptone nutrient medium, prepared with artificial sea water and supplemented with $\mathrm{NaCl}$ concentrations of $0,0 \cdot 5,1,3,5,8$, 10,12 and $15 \%(\mathrm{w} / \mathrm{v})$. Ability to use phenol as the sole carbon source was determined on minimal media that contained 2 or $5 \% \mathrm{NaCl}(\mathrm{w} / \mathrm{v})$ and $4 \mathrm{mM}$ phenol for up to 7 days incubation. Leifson's oxidation-fermentation medium for marine bacteria (Leifson, 1963) was used to test acid production from carbohydrates with $1 \%(\mathrm{w} / \mathrm{v})$ of each compound. Other biochemical tests were carried out by using API 20NE test kits (bioMérieux) according to the manufacturer's instructions, except that the culture was suspended in $2 \%(\mathrm{w} / \mathrm{v}) \mathrm{NaCl}$ solution, and by the Biolog GN MicroPlate panel. For the latter tests, strain KMM $3654^{\mathrm{T}}$ was grown on MA at $28^{\circ} \mathrm{C}$ for $24 \mathrm{~h}$ and Biolog microtitre plates were inoculated with cells suspended in $2 \%(\mathrm{w} / \mathrm{v})$ $\mathrm{NaCl}$ solution. Results were read automatically with a spectrophotometer after 24 and $48 \mathrm{~h}$ incubation at $28^{\circ} \mathrm{C}$. For lipid analysis, the strain was cultivated on MA at $28^{\circ} \mathrm{C}$ for 2 days. Fatty acid methyl esters were prepared from cells by acid-catalysed transmethylation and analysed by GLC. Whole-cell fatty acids and phospholipids were examined according to procedures described previously (Svetashev et al., 1995; Ivanova et al., 2000). DNA G + C content was 


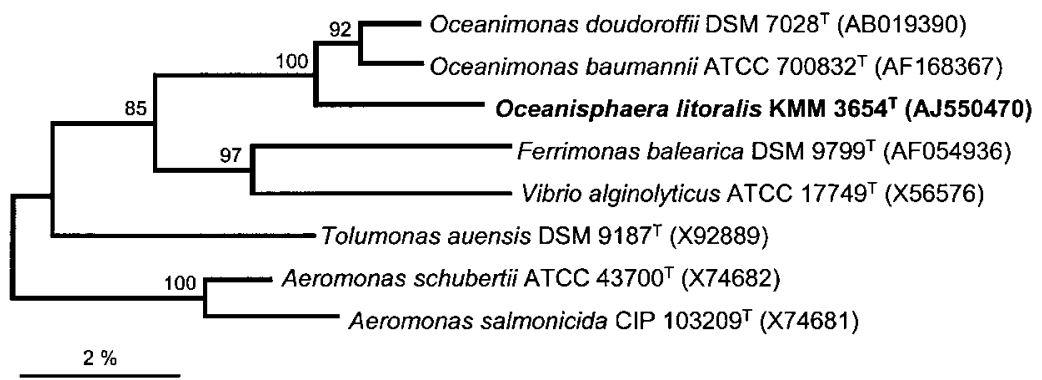

Fig. 1. Dendrogram of $16 \mathrm{~S}$ rRNA gene sequence relatedness, showing the phylogenetic position of strain $\mathrm{KMM} 3654^{\top}$ next to members of the genus Oceanimonas and less closely related species of the $\gamma$ Proteobacteria. Numbers at branching points refer to bootstrap values (500 resamplings). Bar, 2 inferred nucleotide substitutions per 100 nucleotides.

determined by HPLC according to the method of Mesbah et al. (1989).

Genomic DNA extraction, PCR-mediated amplification of the 16S rRNA gene and sequencing of PCR products were carried out as described by Rainey et al. (1996). Purified PCR products were sequenced directly by using a Taq DyeDeoxy Terminator Cycle Sequencing kit (Applied Biosystems) according to the manufacturer's instructions. An Applied Biosystems 310 Genetic Analyzer was used for electrophoresis of sequence reaction products. The $16 \mathrm{~S}$ rDNA sequence of strain KMM $3654^{\mathrm{T}}$ was aligned manually with nucleotide sequences obtained from GenBank/EMBL. The method of Jukes \& Cantor (1969) was used to calculate evolutionary distances. Accession numbers of reference strains used in the phylogenetic analysis are shown in Fig. 1.

Phylogenetic analysis based on the almost-complete $16 \mathrm{~S}$ rRNA gene sequence (1505 nt) of strain KMM $3654^{\mathrm{T}}$ indicated that $O$. doudoroffii DSM $7028^{\mathrm{T}}$ and $O$. baumannii ATCC $700832^{\mathrm{T}}$ (Brown et al., 2001) were the closest phylogenetic neighbours, respectively displaying 96.7 and $95 \cdot 6 \%$ sequence similarity to strain KMM $3654^{\mathrm{T}}$. Ferrimonas balearica DSM $9799^{\mathrm{T}}$ (Rosselló-Mora et al., 1995), Tolumonas auensis DSM $9187^{\mathrm{T}}$ (Fischer-Romero et al., 1996) and members of the families Vibrionaceae, Enterobacteriaceae and Aeromonadaceae were more distantly related $(<92 \%$ sequence similarity). This relationship is displayed in the $16 \mathrm{~S}$ rRNA gene sequence dendrogram based on the additive treeing algorithm of DeSoete (1983) (Fig. 1). Based on moderate sequence similarity of $<97 \%$, the novel isolate can be considered to be a separate taxonomic entity from the two described species of the genus Oceanimonas (Stackebrandt \& Goebel, 1994), which share only $38.6 \%$ DNA similarity (Brown et al., 2001).

Chemotaxonomically, isolate KMM $3654^{\mathrm{T}}$ shared properties that were also reported for the two species of the genus Oceanimonas (Brown et al., 2001), i.e. whole-cell fatty acids, phospholipids and DNA G+C content of $56 \cdot 4 \mathrm{~mol} \%$, which is similar to those reported for $O$. doudoroffii DSM $7028^{\mathrm{T}}$ and O. baumannii ATCC $700832^{\mathrm{T}}$ (each $54 \mathrm{~mol} \%$ ). High amounts (up to $90 \%$ of the total) of fatty acids $\mathrm{C}_{16: 0}$, $\mathrm{C}_{16: 1}$ cis and $\mathrm{C}_{18: 1}$ cis found in strain $\mathrm{KMM} 3654^{\mathrm{T}}$ were also reported for Oceanimonas species (Brown et al., 2001). Quantitative analysis is given in the species description. KMM $3654^{\mathrm{T}}$ contained phosphatidylethanolamine and phosphatidylglycerol ( $43 \cdot 7$ and $46.9 \%$, respectively) as the main phospholipids. These compounds were also found in the two Oceanimonas species; KMM $3654^{\mathrm{T}}$ differed from these species in the lack of fatty acid $\mathrm{C}_{12: 0}$ and in a higher proportion $(9 \cdot 4 \%)$ of diphosphatidylglycerol.

Strain KMM $3654^{\mathrm{T}}$ was aerobic, Gram-negative, moderately halophilic and oxidase- and catalase-positive. Cells were coccoid, $1 \cdot 0-1 \cdot 2 \mu \mathrm{m}$ in diameter, encapsulated and motile by a single polar flagellum (Fig. 2a). Cells grown on hard media occurred as single motile or non-motile cells, due to their ability to lose flagella easily, and formed aggregates and some fibrillar structures when cultivated in liquid media (Fig. 2b). The isolate required sodium ions for growth and grew in $0 \cdot 5-10 \% \mathrm{NaCl}$ at $4-42^{\circ} \mathrm{C}$, with optima between 1 and $3 \% \mathrm{NaCl}$ and 28 and $35^{\circ} \mathrm{C}$, respectively. After $24 \mathrm{~h}$ on MA, strain KMM $3654^{\mathrm{T}}$ produced smooth,

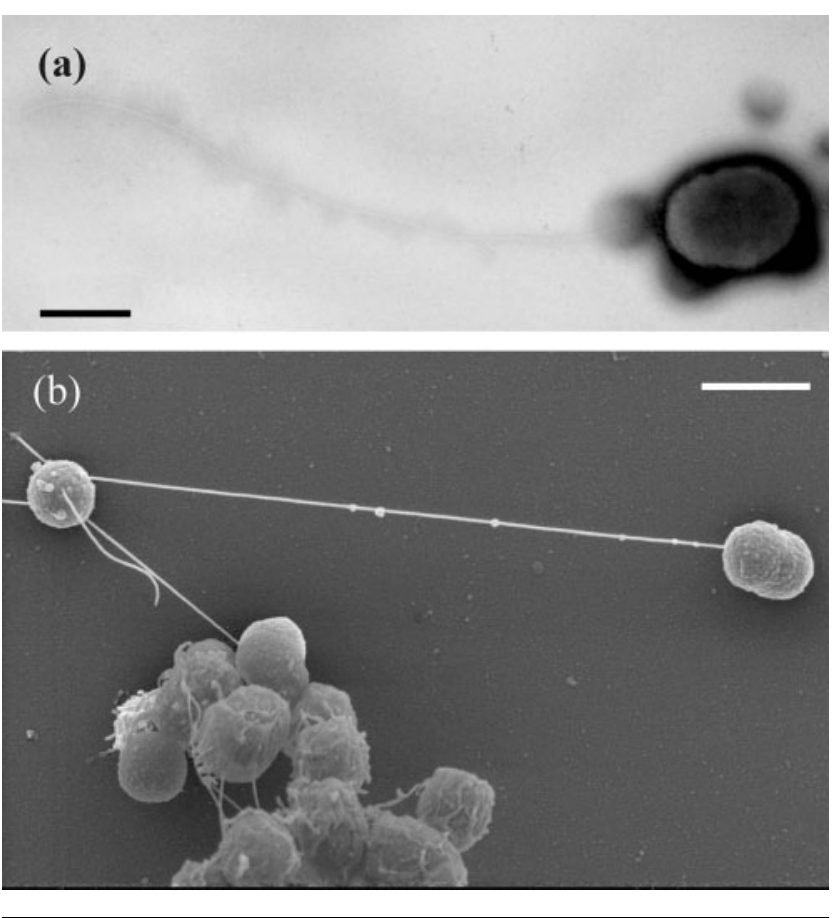

Fig. 2. Transmission (a) and scanning (b) electron micrographs of strain $\mathrm{KMM} 3654^{\top}$ grown in $\mathrm{MB}$, showing spherical cell shape, polar flagella and cell aggregates. Bars, (a) 1 and (b) $2 \mu \mathrm{m}$. 
shining, slightly yellow colonies with regular edges that were 3-5 $\mathrm{mm}$ in diameter. Diffusion of yellowish pigment into the medium was observed. Growth was weak or delayed for 5-7 days when cultivated in minimal salts medium that contained $2 \% \mathrm{NaCl}$ and phenol as the sole carbon and energy source, which was used to cultivate strains of Oceanimonas (Brown et al., 2001), but growth did not occur in this medium when the salinity was raised to $5 \%$. The main phenotypic characteristics of strain $\mathrm{KMM} 3654^{\mathrm{T}}$ and related Oceanimonas species are shown in Table 1.

Unlike members of the genus Oceanimonas, the new isolate is yellowish-pigmented, encapsulated, coccoid, able to form aggregates and external fibrillar-like structures, able to grow at $4{ }^{\circ} \mathrm{C}$ and up to $10 \% \mathrm{NaCl}$, produces urease and utilizes phenylacetate and does not utilize ethanol, succinate, L-alanine or L-proline. Heissenberger et al. (1996) observed production of exopolymer and, in addition, fibrillar material that connected marine bacterial cells. The capsular envelope has been hypothesized to play a basic role in bacterial attachment to surfaces in marine environments. Taking into consideration the fact that the habitat of KMM $3654^{\mathrm{T}}$ is marine sand sediment, the

Table 1. Phenotypic characteristics of strain $\mathrm{KMM} 3654^{\top}$ and related Oceanimonas species

Taxa: 1, KMM $3654^{\mathrm{T}}$; 2, Oceanimonas doudoroffii DSM $7028^{\mathrm{T}}$; 3, Oceanimonas baumannii ATCC $700832^{\mathrm{T}}$. Data for Oceanimonas species were taken from Brown et al. (2001). All strains are positive for oxidase, catalase, $\mathrm{Na}^{+}$requirement for growth, nitrate reduction $^{\star}$, malate $^{\star}$ and citrate $^{\star}$ utilization and negative for indole production $^{\star}$, arginine dihydrolase ${ }^{\star}$, gelatin and aesculin hydrolysis ${ }^{\star}$ and utilization of glucose ${ }^{\star}$, arabinose $^{\star}$, mannose $e^{\star}$, mannitol $^{\star}, \mathrm{N}$ acetylglucosamine $e^{\star}$, maltose $^{\star}$, gluconate ${ }^{\star}$, adipate ${ }^{\star}$, sucrose, Lleucine, L-valine and L-tyrosine.

\begin{tabular}{|lccc|}
\hline Characteristic & $\mathbf{1}$ & $\mathbf{2}$ & $\mathbf{3}$ \\
\hline Cell morphology & Coccoid & Rod-shaped & Rod-shaped \\
Cell size $(\mu \mathrm{m})$ & $1 \cdot 0-1 \cdot 2$ & $0 \cdot 7-1 \cdot 2 \times$ & $2 \times 1$ \\
& & $2 \cdot 0-2 \cdot 5$ & \\
Growth temperature $\left({ }^{\circ} \mathrm{C}\right)$ & $4-42$ & $10-41$ & $10-41$ \\
Urease & + & - & - \\
Utilization of: & & & \\
Caprate & - & + & + \\
Phenylacetate & + & - & - \\
Galactose & - & - & + \\
Glycerol & - & - & + \\
Ethanol & - & + & + \\
Phenol & $\mathrm{W}$ & + & + \\
Succinate & - & + & + \\
L-Glutamate & $\mathrm{W}$ & + & + \\
L-Proline & - & + & + \\
L-Alanine & - & + & + \\
DNA G + C content $(\mathrm{mol} \%)$ & $56 \cdot 4$ & 54 & 54 \\
& & & \\
\hline
\end{tabular}

${ }^{\star}$ Determined by the API 20NE test (this study and Brown et al., 2001). formation of cell aggregates and capsular and fibrillar-like materials may be a useful cellular adaptation for attachment to surfaces. Strain KMM $3654^{\mathrm{T}}$ lacked the ability to degrade phenol, which is positive for $O$. doudoroffii and O. baumannii (Brown et al., 2001). The new isolate exhibited weak reactions for utilization of Tween 40, Tween 80, $\alpha$-ketobutyric acid, $\alpha$-ketovaleric acid and L-glutamic acid and did not utilize most of the carbohydrates, organic acids or amino acids provided by the API 20NE and Biolog substrate panels (Table 1).

Strain KMM $3654^{\mathrm{T}}$ can be distinguished from members of the genus Oceanimonas by using a combination of biochemical characteristics (Table 1) and phylogenetic distance (Fig. 1). Based on these results, we propose to classify isolate KMM $3654^{\mathrm{T}}$ in a novel genus and species, Oceanisphaera litoralis gen. nov., sp. nov., with the type strain KMM $3654^{\mathrm{T}}\left(=\mathrm{DSM} 15406^{\mathrm{T}}\right)$.

\section{Description of Oceanisphaera gen. nov.}

Oceanisphaera (O.ce.a.ni.sphae'ra. L. masc. n. oceanus ocean; L. fem. n. sphaera ball, globe, sphere; N.L. fem. n. Oceanisphaera oceanic sphere).

Spherical cells, $1 \cdot 0-1 \cdot 2 \mu \mathrm{m}$ in diameter and motile by means of flagella. Gram-negative chemoorganotroph with absolute requirement for sodium ions. Aerobic. Moderately halophilic and oxidase- and catalase-positive. Major phospholipids are phosphatidylethanolamine, phosphatidylglycerol and diphosphatidylglycerol. Major fatty acids are $\mathrm{C}_{16: 0}, \mathrm{C}_{16: 1} \omega 7 c$ and $\mathrm{C}_{18: 1} \omega 7 c$. DNA $\mathrm{G}+\mathrm{C}$ content is $56.4 \mathrm{~mol} \%$ (HPLC). Isolated from a marine environment. Phylogenetically related to the genus Oceanimonas in the $\gamma$-Proteobacteria. The type species is Oceanisphaera litoralis.

\section{Description of Oceanisphaera litoralis sp. nov.}

Oceanisphaera litoralis (li.to.ra'lis. L. fem. adj. litoralis of or belonging to the seashore).

Gram-negative, aerobic, oxidase- and catalase-positive, motile by a single polar flagellum, spherical, encapsulated single cells that are $1 \cdot 0-1 \cdot 2 \mu \mathrm{m}$ in diameter. May be nonmotile. Able to form aggregates and fibrillar structures when cultivated in liquid media. Moderately halophilic, does not grow without sodium ions; grows in $0.5-10 \% \mathrm{NaCl}$ at $4-42^{\circ} \mathrm{C}$, but not at $44^{\circ} \mathrm{C}$. On MA, strain KMM $3654^{\mathrm{T}}$ produces smooth, shining, yellowish colonies with regular edges that are 3-5 $\mathrm{mm}$ in diameter after $24 \mathrm{~h}$ incubation at $28^{\circ} \mathrm{C}$. Gelatin, casein, aesculin, starch, DNA and chitin are not hydrolysed. No acid is produced from glucose, sucrose, maltose, lactose, $\mathrm{N}$-acetylglucosamine, arabinose, rhamnose, galactose, glycerol or mannitol. Positive for nitrate reduction, urease activity and utilization of malate, citrate and phenylacetate. Metabolic properties are indicated in Table 1. According to Biolog system identification tests, KMM $3654^{\mathrm{T}}$ weakly utilizes Tween 40 , Tween 80 , $\alpha$-ketobutyric acid, $\alpha$-ketovaleric acid and L-glutamic acid. The rest of the organic substrates included in the Biolog 
panel are not utilized. Main fatty acids are $\mathrm{C}_{16: 0}(21 \cdot 6 \%)$, $\mathrm{C}_{16: 1} \omega 7 c(41 \cdot 0 \%)$ and $\mathrm{C}_{18: 1} \omega 7 c(27 \cdot 5 \%)$; minor amounts of $\mathrm{C}_{15: 0}(1.8 \%)$, iso- $\mathrm{C}_{16: 0}(1.6 \%), \mathrm{C}_{17: 0}(1.9 \%)$ and $\mathrm{C}_{17: 1} \omega 8 c(1.9 \%)$ are present. Phospholipids consist of phosphatidylethanolamine $(43.7 \%)$, phosphatidylglycerol $(46 \cdot 9 \%)$ and diphosphatidylglycerol $(9 \cdot 4 \%)$. DNA G + C content is $56 \cdot 4 \mathrm{~mol} \%$ (HPLC).

The type strain is KMM $3654^{\mathrm{T}}$ (=DSM $15406^{\mathrm{T}}$ ). Isolated from a bottom sand sample, Peter the Great Bay, Sea of Japan, Pacific Ocean, Russia.

\section{Acknowledgements}

This study was supported by grant no. 02-04-49517 from the Russian Foundation for Basic Research and by grant no. 95-01/03-19 from the Russian State Committee for Science and Technologies. The technical assistance of Ina Kramer and Jolantha Swiderski is gratefully acknowledged.

\section{References}

Baumann, L., Baumann, P., Mandel, M. \& Allen, R. D. (1972). Taxonomy of aerobic marine eubacteria. J Bacteriol 110, 402-429.

Brown, G. R., Sutcliffe, I. C. \& Cummings, S. P. (2001). Reclassification of [Pseudomonas] doudoroffii (Baumann et al. 1983) into the genus Oceanomonas gen. nov. as Oceanomonas doudoroffii comb. nov., and description of a phenol-degrading bacterium from estuarine water as Oceanomonas baumannii sp. nov. Int J Syst Evol Microbiol 51, 67-72.

DeSoete, G. (1983). A least squares algorithm for fitting additive trees to proximity data. Psychometrika 48, 621-626.

Fischer-Romero, C., Tindall, B. J. \& Jüttner, F. (1996). Tolumonas auensis gen. nov., sp. nov., a toluene-producing bacterium from anoxic sediments of a freshwater lake. Int J Syst Bacteriol 46, 183-188.
Heissenberger, A., Leppard, G. G. \& Herndl, G. J. (1996), Relationship between the intracellular integrity and the morphology of the capsular envelope in attached and free-living marine bacteria. Appl Environ Microbiol 62, 4521-4528.

Ivanova, E. P., Zhukova, N. V., Svetashev, V. I., Gorshkova, N. M., Kurilenko, V. V., Frolova, G. M. \& Mikhailov, V. V. (2000). Evaluation of phospholipid and fatty acid compositions as chemotaxonomic markers of Alteromonas-like Proteobacteria. Curr Microbiol 41, 341-345.

Jukes, T. H. \& Cantor, C. R. (1969). Evolution of protein molecules. In Mammalian Protein Metabolism, pp. 21-132. Edited by H. N. Munro. New York: Academic Press.

Leifson, E. (1963). Determination of carbohydrate metabolism of marine bacteria. J Bacteriol 85, 1183-1184.

Mesbah, M., Premachandran, U. \& Whitman, W. B. (1989). Precise measurement of the $\mathrm{G}+\mathrm{C}$ content of deoxyribonucleic acid by highperformance liquid chromatography. Int J Syst Bacteriol 39, 159-167.

Rainey, F. A., Ward-Rainey, N., Kroppenstedt, R. M. \& Stackebrandt, E. (1996). The genus Nocardiopsis represents a phylogenetically coherent taxon and a distinct actinomycete lineage: proposal of Nocardiopsaceae fam. nov. Int J Syst Bacteriol 46, 1088-1092.

Rosselló-Mora, R., Ludwig, W., Kämpfer, P., Amann, R. \& Schleifer, K. H. (1995). Ferrimonas balearica gen. nov., sp. nov, a new marine facultative Fe(III)-reducing bacterium. Syst Appl Microbiol 18, 196-202.

Smibert, R. M. \& Krieg, N. R. (1994). Phenotypic characterization. In Methods for General and Molecular Bacteriology, pp. 607-655. Edited by P. Gerhardt, R. G. E. Murray, W. A. Wood \& N. R. Krieg. Washington, DC: American Society for Microbiology.

Stackebrandt, E. \& Goebel, B. M. (1994). Taxonomic note: a place for DNA-DNA reassociation and 16S rRNA sequence analysis in the present species definition in bacteriology. Int J Syst Bacteriol 44, 846-849.

Svetashev, V. I., Vysotskii, M. V., Ivanova, E. P. \& Mikhailov, V. V. (1995). Cellular fatty acids of Alteromonas species. Syst Appl Microbiol 18, 37-43. 